DOI 10.22460/infinity.v6i2.p169-176

\title{
ANALYSIS OF STUDENTS' LEARNING OBSTACLES ON LEARNING INVERS FUNCTION MATERIAL
}

\author{
Krisna Satrio Perbowo ${ }^{1}$, Restu Anjarwati ${ }^{2}$ \\ ${ }^{1}$ University of Muhammadiyah Prof. DR. HAMKA, J1. Tanah Merdeka, Jakarta Timur, Indonesia \\ ${ }^{2}$ SMA IT Al Marjan, Jl. Perintis I, Jatikramat, Jatiasih, Bekasi, Indonesia \\ ${ }^{1}$ krisna_satrio@uhamka.ac.id, ${ }^{2}$ restu.sukamatika@gmail.com
}

Received: March 04, 2017 ; Accepted: July 11, 2017

\begin{abstract}
This research is based on the presence of obstacle in learning mathematics on inverse function. This research aims to analyze the learning obstacle, to know the types of error that is suffered by the students in learning inverse function. Kind of this kualitative research descriptive with data triangulation. The research subjects are high school students which is contained of 74 students and was taken 6 students to be main sample. The data of students' error is obtained from the writen test result, the students' false answers are identified into the type of error. Then it was chosen several students to be interviewed. Which the analysis result finding data in this research showed there are 4 types of errors, which are concept error, procedure error, counting error and concluding error. An obstacle which appear in learning inverse function is influenced by two factors, i.e internal factor and eksternal factor. Internal factor is showed by the students' motivation in following learning and students' skill in receiving learning material. While the eksternal factor is showed by the curriculum which applied in school with acceleration class caused many narrow learning time, teaching materials that is less complete with the discussion of question sample.
\end{abstract}

Keywords: Inverse Function, Learning Obstacle, Learning Process.

\begin{abstract}
Abstrak
Penelitian ini didasarkan pada keberadaan hambatan dalam pembelajaran matematika materi fungsi invers. Tujuan penelitian ini adalah untuk menganalisa hambatan belajar dan jenisnya, sebagaimana dialami siswa saat mempelajari fungsi invers. Penelitian ini menggunakan metode deskriptif kualitatif dengan triangulasi data. Subjek penelitian ini adalah 74 siswa sekolah menengah atas dan diambil 6 siswa sebagai sampel utama untuk diwawancara. Tes digunakan untuk memperoleh data kesalahan siswa, selanjutnya tipe kesalahan diperoleh dari identifikasi jawaban yang salah. Berdasarkan hasil temuan, diperoleh 4 tipe kesalahan yaitu kesalahan konsep, kesalahan prosedur, kesalahan perhitungan, dan kesalahan penyimpulan. Hambatan yang muncul dalam mempelajari fungsi invers dipengaruhi 2 faktor, yaitu eksternal dan internal. Faktor internal terlihat dari motivasi siswa dalam mengikuti pembelajaran dan kemampuan siswa menerima materi pembelajaran. Sedangkan faktor eksternal adalah penerapan kurikulum kelas akselerasi yang diterapkan sekolah mengakibatkan pendeknya waktu belajar, bahan ajar yang kurang lengkap dalam mendiskusikan contoh soal.
\end{abstract}

Kata Kunci: Fungsi Invers, Hambatan Belajar, Proses Belajar.

How to Cite: Perbowo, K. S., \& Anjarwati, R. (2017). Analysis of Students' Learning Obstacles on Learning Invers Function Material. Infinity, 6 (2), 169-176. doi:10.22460/infinity.v6i2.p169-176 


\section{INTRODUCTION}

The problems that arise in the education system in Indonesia are very complex, including mathematics learning problems. Mathematics is basic knowledge that is required to proceed to every level of education (Nuriadin \& Perbowo, 2013). At the high school, there is math standard material components of which are a function in mathematics. In this concept is specified in the discussion of inverse function. At school learning in Indonesia, material inverse functions listed in the Competency Standards Graduates in mathematics secondary level is "Understanding and determine the conditions for a function has an inverse, determine the rules of the inverse function of a function, identify the nature of inverse functions, drawing graphs inverse function of graph of the function of origin ". In fact, to achieve the Graduate Competency Standards there are some obstacles. In the short interview with one of the high school students who learns the inverse function, think that the material is easy because they can use the quick way. However, students complain of difficulties in terms of translation algebraically in determining the inverse function.

According to Ignacio, Barona, \& Nieto (2006), teachers need to recognize and analyze about how students hold certain beliefs when learning mathematics and interacting with their environment, the success or failure were leaded by these beliefs. Students' error in response to any math problems is often not followed up by tracking the occurrence of obstacles during the learning process. In addition, it seems that teachers' view of sources of the students' learning obstacle have received less attention in mathematics education research and literature (Bingolbali, Akkoç, Ozmantar, \& Demir, 2011). It is possible there are still other difficulties related with material that can be found inverse function which if necessary to find the causes. In this case, teachers must help their students to develop persistence and broader students' view of mathematics (Schackow \& Thompson, 2005; Saija, 2012).

The urge to break the barriers in learning which is experienced by students should be developed by one element of the development of the teaching profession. Learning mathematics took place regarding to teachers, students and mathematics itself. The learning process is based solely on textual understanding of teaching materials such as only books that will lead to poor learning the meaning and context, as well as the learning process resultsoriented will result in the student passively. Student learning difficulties indicated by the presence of certain obstacles to achieve the learning outcomes can be psychological, sociological, and physiological, which in turn can lead to decreased academic achievement accomplished.

Mathematics became an essential part of life, not only became one of the requirements to proceed to every level of education, even mathematics is widely used for everyday life. E.g. market sellers who use scales, builder, driver and almost all aspects of life require mathematics. On a wider scope of mathematics is the queen and servant of science knowledge of the other.

Jhonson (Suherman, 2003) says that mathematics is the study of patterns and relationships, a road or a pattern of thought, an art, a language and a tool. The researchers concluded that mathematics is a science that is obtained by reasoned that using the terms defined carefully, clearly and accurately, represented by the symbol of language and symbols that have meaning. 
Benefits of mathematics are not just limited to the knowledge and calculation, but more importantly when each individual can master math well, the pattern of their thinking became more rational and critical. According to the Permendiknas No.22 In 2006 on Content Standards, mathematics courses should be treated to all students with the ability to think logically, analytical, systematic, critical, and creative, and able to work together. Competence is needed so that learners can have the ability to acquire, manage, and use information to survive in a state that is always changing, uncertain and competitive.

The purpose of learning is to acquire new knowledge. In the process of development of knowledge, an individual often encounter obstacles or barriers. Barriers are anything that obstruct, hinder, impede or individual human encountered in everyday life that come and go, creating barriers for the individuals who experience it. Barriers in learning are essentially a phenomenon that appears in different types of manifestations of behavior. Symptoms of obstacles are directly manifested in a variety of behaviors. Behavior manifested by the presence of certain barriers, will usually be seen in aspects of motoric, cognitive and affective, well into the process and learning outcomes are achieved.

Cornu (2002) distinguishes between four types of obstacle, namely: cognitive barriers, genetic and psychological barriers, and barriers didactic and epistemological barriers. In this study, researcher sought to focus on the students' learning barriers in understanding the concept of inverse functions, from the aspect of epistemology. Basically, the establishment of knowledge occurs through the interaction of subsystems. Brousseau (2002) explains that one of the learning sub-systems consists of teachers, students, and system knowledge.

The third involvement in the learning subsystem supports the creation of knowledge. Interaction among the three becomes an important part of learning. Nothing is in focus or emphasis; all three must go hand in hand because if there focusing on one of the subsystems will be an imbalance.

In explaining the epistemological obstacle, it is indicates that: Barriers epistemology occurs in the development of scientific thought and in practical education (Cornu, 2002). Cornu and Bachelard (Tall, 2002) said that epistemological obstacles has two important advantages: a) They can not respond and understand the new knowledge gained b) They are only able to respond a little bit of a concept that has been previously understood.

This means that the barriers epistemology greatly affect the learning concepts that have been studied previously. Effect of prior knowledge will support the new knowledge to be gained. Barriers epistemology of scientific knowledge may lead to stagnation, and even decline in someone's knowledge.

\section{METHOD}

Based on the problems studied, the researchers chose descriptive analysis as type of this research. Researchers collected data based on observations of natural situation as it is without being influenced and deliberated. Researchers as a research instrument "human instrument". In this case the researchers are a key instrument, or so-called "key instrument", held their own observations or interviews were unstructured, often just using a notebook and camera. Descriptive data were collected as many as outlined in report form. 
In this study, the research subject are Science Class majors students in senior high school. In this study to determine the barriers to student learning are in depth after analyzing the test results. The researchers conducted interviews to the students of class $11^{\text {th }}$ grade were taken from 3 and of $12^{\text {th }}$ grade were taken 3 . As explained in table 1 below:

Table 1. Number of Samples

\begin{tabular}{ccc}
\hline Research Subject & Amount & Code \\
\hline Students of $11^{\text {th }}$ grade & 3 & A1, A2, A3 \\
Students of $12^{\text {th }}$ grade & 3 & B1, B2, B3 \\
\hline Total & 6 & 66 \\
\hline
\end{tabular}

This study emphasizes the filter information in a narrative form. Instruments which are used such as: a) test problem-solving ability to get research subjects. b) Interview guide to locate the difficulties of students who received a low score based on problem-solving abilities in solving the problem of the inverse function. c) The validation of matter, to determine whether the instrument is made by the researcher actually valid or not, and the instrument must be validated by the validator. d) To test the validity of an instrument to strengthen eligibility to be tested, the validity of the instrument consists of 10 questions that include indicators on the mathematical problem solving material inverse function.

Data collection techniques which were used in this study included the identification of barriers to learning and categorization of barriers to learning. For a more in-depth data reveal researchers also conducted observations and interviews. In qualitative research would be found on data obtained from various sources, using the techniques of data collection manifold (triangulation), and carried out continuously until data saturation. Data saturation is a state of the data does not change when the researchers took samples of up repeatedly.

\section{RESULTS AND DISCUSSION}

\section{Results}

Results of analysis tests students' skills in solving problems associated with the function and the inverse function, error grouped students by using tables and classified into types of errors. Many errors appear in the data presented in the form of a percentage.

Based on the test results of students' skills in solving problems related to learning functions and inverse functions derived from all 74 students were given the test, it appears that the errors appear different in each child. This type of error is classified into four types of errors, the errors concept, procedural errors, miscalculations and concluding errors (Widdiharto 2008). The details of the problem-solving test results based on the type of error can be seen in table 2 below.

Table 2. Precentaage of students' errors in solving function problem and invers function

\begin{tabular}{ccc}
\hline Types of Errors & $\mathbf{1 1}^{\text {th }}$ grade & $\mathbf{1 2}^{\text {th }}$ grade \\
\hline Concept errors & $32 \%$ & $8,20 \%$ \\
Procedural errors & $15,30 \%$ & $33,50 \%$ \\
Miscalculation & $28,90 \%$ & $21,20 \%$ \\
Concluding errors & $23,60 \%$ & $36,90 \%$ \\
\hline
\end{tabular}




\section{Discussion}

The instrument were used in this study consisted of 10 questions related to problem-solving abilities to seek resolution of functions and inverse functions. The strategy, which is used by students in problem solving functions and inverse functions was demonstrated in Figure 1 for Question 1, namely students solve problems by determining the value of the function of the operation of algebra functions obtainable strategies used by students A33 is by substitution of data into the equation and calculated based structure.

$$
\begin{aligned}
& \text { Problem: } \\
& \left(1+\sqrt{2}^{2}\right)-3(1+\sqrt{2})^{2} \\
& \text { Solution: } \\
& \left(1+\sqrt{2}^{2}\right)-3(1+\sqrt{2})^{2} \\
& =1+2-3-3 \sqrt{2}+1 \\
& =1-3 \sqrt{2}
\end{aligned}
$$

Figure 1. Case 1

\section{Interview 1}

Researcher : How do you solve question 1?

A33 : Expand it algebraicly, then proceed the operation

Researcher : Do you know about principle of exponent?

A33

: I don't remember

The Conclusion is the answer is not correct because it does not use the principle of exponent characteristic and the mistake in operating the algorithm.

In figure 2, question number 5 test students' ability to solve problems related to the composition of functions, obtained strategies used by students A33 i.e, with substitute function $f$ into a function $g$, but at later stage does not give the appropriate conclusions 


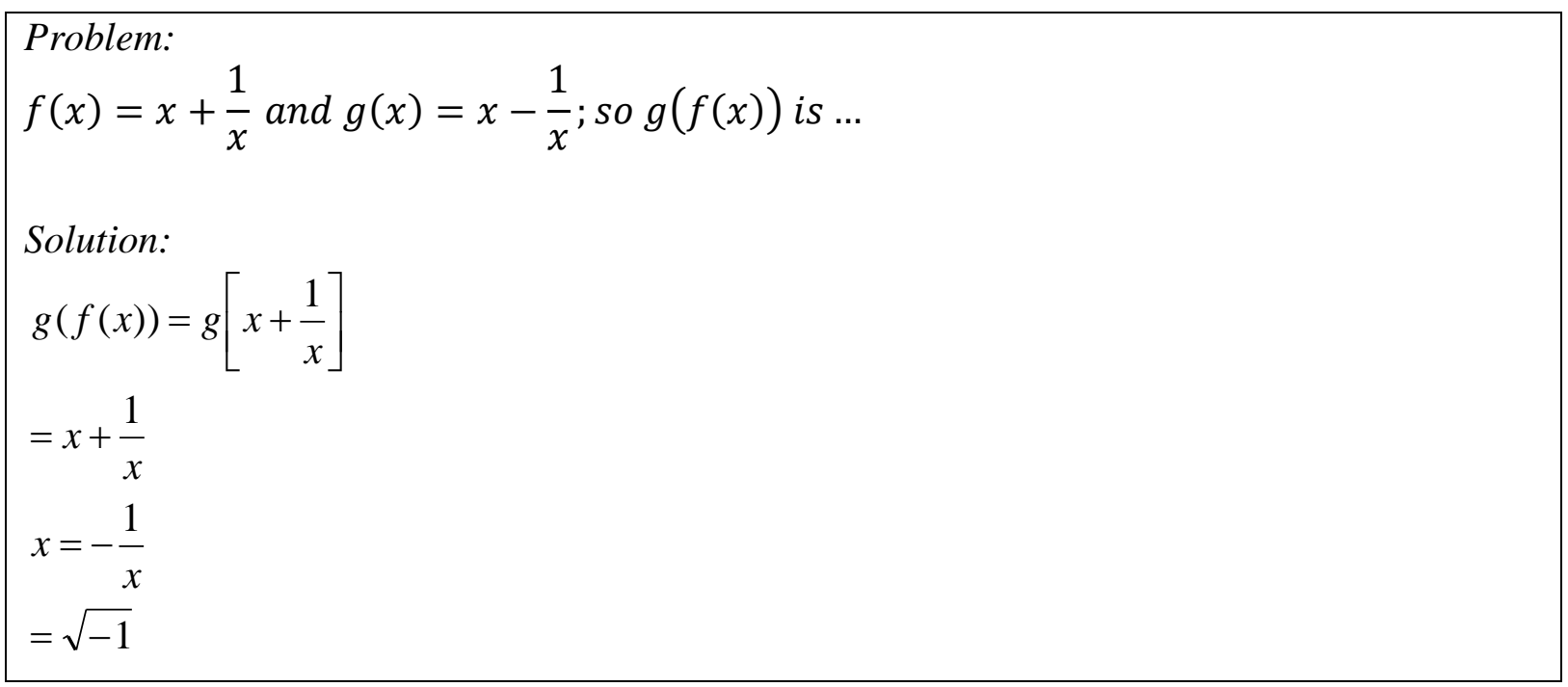

Figure 2. Case 2

\section{Interview 2}

Researcher : How do you solve question 5?

A33 : Simply substitute the function and find the value of $x$

The Conclusion is the result is not appropriate because there is a mistake in algebraic operation, especially in substituting the function form.

On the student A33, test results which have been obtained, shows that student misconceptions A33 appeared 9 times, 3 times procedural errors, miscalculations and mistakes concluded 5 times as much as 8 times. This suggests that students experience an error in the working section selecting information incorrect data, using the principle of a formula or procedure incorrectly, students lost one of data or more, less accurate in the calculation and use of the proper way, but did not manage to conclude well, and showed a lower operating to draw conclusions.

This explanation is reinforced by interviews conducted by researchers. Students A33 coupled with the observation of the results of the answers that students provide, it is known that students have difficulty in concluding the final result because there is a concept that does not remember that the rules regarding the nature of exponents. Based on the above data can be explained that many students have difficulty in mathematical problem solving process on inverse function subject. The students do not mastering the concept of algebraic function, more because of they do not have enough fundamental prerequisites ability for algebraic function. On the other hand, the students used algebraic properties carelessly. Furthermore, the students were experiencing internal resistance, i.e. do not know the benefits from studies, learning materials may be accepted depending on emotional condition and external constraints, the teacher gives questions that has never been taught, teachers are sometimes less interactive, and curriculum foundations make students become less exercise in the discussion of each section in which one section is given training in schools is only one time. All the issues above are causing many problems not solved corectly with appropiate algebraic prosedures. This proves that many obstacle in learning, happened both from internal and 
external. This is in line with Hidayat research (2017) which suggests that high school students in mathematics subjects still tend to lack the novelty of the mathematical reasoning ability so that completion is still following routine procedures.

\section{CONCLUSION}

From this research, it can be concluded that, students solved invers function problems using quick and short algorithm, so they ignore the rules of mathematics itself. Students become less rigorous in algebraic computational operations. But, from this study, we did not found any different strategy in solving the functions problems and inverse functions problems. So it is monotonous.

According to this study, also found some types of errors that appear from students in related to inverse function subject. Namely, misconceptions that causing errors in understanding mathematics concepts, which become the prerequisites and concepts being taught; errors by discrepancy procedure steps in order to responding the problem, so that there is no clear layout in the process of answers finding; and calculation error caused by unappropiate numeracy ability and knowledge, so sutdents can not do the calculation correctly. While, the epistemological barriers found in this study are students did not understand the material prerequisites in order to studying the function and the inverse function, namely the rules of exponents. Else, students have lack of understanding on the concept of algebraic functions, so they found it difficult in solving problems. In addition, the students were not understand on how to simplify fractions form, which causing poor intact in understanding algebraic functions.

\section{REFERENCES}

Bingolbali, E., Akkoç, H., Ozmantar, M. F., \& Demir, S. (2011). Pre-Service and In-Service Teachers $^{\text {ee }}$ Views of the Sources of Studentse ${ }^{\text {ee }}$ Mathematical Difficulties. International Electronic Journal of Mathematics Education, 6(1), 40-59.

Brousseau, G. (2002). Theory of Didactical Situations in Mathematics. (N. Balacheff, M. Cooper, R. Sutherland, \& V. Warfield, Eds.) (1st ed., Vol. 19). Dordrecht: Kluwer Academic Publishers. https://doi.org/10.1007/0-306-47211-2

Cornu, B. (2002). Limits. In D. Tall (Eds.), Advanced Mathematical Thinking, 153-166. Dordrecht: Kluwer Academic Publishers.

Euis, S. (2011). Hambatan Epistemologi (Epistemological Obstacles) Dalam Persamaan Kuadrat Pada Siswa Madrasah Aliyah. Proceedings International Seminar and the Fourth National Conference on Mathematics Education. Yogyakarta: Yogyakarta State University

Hidayat, W. (2017). Adversity Quotient dan Penalaran Kreatif Matematis Siswa SMA dalam Pembelajaran Argument Driven Inquiry pada Materi Turunan Fungsi. KALAMATIKA Jurnal Pendidikan Matematika, 2(1), 15-28.

Ignacio, N. G., Barona, E. G., \& Nieto, L. B. (2006). The affective domain in learning mathematics. Electronic Journal of Research in Educational Psychology, 4(1), 47-72.

Nuriadin, I., \& Perbowo, K. S. (2013). Analisis Korelasi Kemampuan Berpikir Kreatif Matematik Terhadap Hasil Belajar Matematika Peserta Didik SMP Negeri 3 Lurangung Kuningan Jawa Barat. Infinity Journal, 2(1), 65-74. 
Saija, L. M. (2012). Analyzing The Mathematical Disposition and Its Correlation with Mathematics Achievement of Abstract Senior High School Students. Infinity Journal, 1(2), 148-152.

Schackow, J. B., \& Thompson, D. R. (2005). High school students' attitudes toward mathematics. Academic Exchange Quarterly, 9(3), 12-19.

Suherman, E. (2003). Strategi Pembelajaran Matematika Kontemporer. Bandung: Universitas Pendidikan Indonesia.

Tall, D. (2002). The Psychology of Advanced Mathematical Thinking. In Advanced Mathematical Thinking (pp. 3-21). Dordrecht: Springer Netherlands.

Widdiharto, R. (2008). Diagnosis Kesulitan Belajar Matematika SMP dan Alternatif Proses Remidinya. Paket Pemberdayaan KKG/MGMP Matematika. Yogyakarta: P4TK Matematika 